\title{
SCHISTOSOMA MANSONI: EFFECTS OF ANESTHETICS AND ANTIMONIAL DRUGS ON WORM SHIFT IN THE MOUSE
}

\author{
José Renan da GưNHA-MELo (1) \& Paulo Marcos Z. COELHo (2)
}

\section{S U M M A R Y}

Mice experimentally infected with Schistosoma mansoni were injected with sodium thiopental or sodium antimonyl gluconate (Triostib R), or submitted to halothane inhalation, with or without a previous injection of thiopental.

Data obtained showed that halothane and thiopental induce worm shift to the liver (99 and $76 \%$, respectively). Sodium gluconate and antimonium (Triostib R) shifted $52 \%$ of worms towards the liver.

These results seem to indicate that the use of antimonium would be unnecessary, when surgical removal of schistosomules is carried out through the extra. corporeal filtration technique, in patients with portal hypertension.

KEY WORDS: Manson schistosomiasis - Experimental disease in mice - Antimonial drugs - Worm shift

\section{NTRODUCTION}

Extracorporeal worm filtration 8,9 has been proposed based on the hypothesis that the simultaneous displacement of a great number of dead worms towards the liver, after treatment, could induce an extensive inflammatory reac. tion in this organ. Nowadays, it is assumed that this problem is not as bigger as it was thought to be at the seventies ${ }^{17}$. However, a significant amount of immunecomplexes is known to be formed stimulated by parasite residues. Considering the daily egg laying by female worms of about 400 , from which $60 \%$ are accumulated in the tissues 16 and depending on the opportunity offered by a patient, who suffering from bilharziasis portal hypertension has to have an operation done, the withdrawal of worms throughout an extracorporeal filtra. tion, in the same surgical act, sounds desirable. The process of filtration was proposed in $19677^{\circ}$ and it is only consictered justifiable if there is a clear indication for surgical treatment of patients with portal hypertension. The technique described included the administration of pentavalent antimony, which acting against the parasites would facilitate their filtration. Nevertheless, the antimony toxicity to the patient constitutes a great inconvenient of the technique.

In our experience with this procedure it was observed that the anesthesia by itself was effective in dislodging the worms towards the liver and distal portal vein lumen, facilitating in that way their remotion by means of a can. nula put in the portal system through the sple. nic vein and connected to a filter system. Should that occur the antimonial injection with the same purpose was dispensable.

The present work was carried out in order to experimentally test this hypothesis using Schistosoma mansoni infected mice.

(1) Departamento de Cirurgia, Faculdade de Medicina da Universidade Federal de Minas Gerais

(2) Departamento de Parasitologia, Instituto de Ciências Blológicas, Universidade Federal de Minas Gersis. Calxa Pos. tal 2486. CEP 30000 Belo Horizonte - MG, Brasil 
CUNFA-MELO, J. R. da \& COELHO, P. M. Z. - Schistosoma mansoni: effects of anesthetios and antimonial drugs worm shift in the mouse. Rev. Inst. Med. trop. São Paulo, 28:267-270, 1986.

\section{MATERIALS AND METHODS}

\section{First experiment}

Female albino mice were subcutaneously infected with about 80 cercariae of Schistoso. ma mansoni, LE strain, Belo Horizonte. Fortysix days later the animals were submitted to tests with the drugs. Sodium thiopental (CEME, Rio de Janeiro) was injected intraperitoneally (1.p.) in doses of 1.25 (Group I) and $2.5 \mathrm{mg} / \mathrm{kg}$ (Group II). A third group was composed by mice injected i.p. with the same doses of thio. pental plus expositian to halothane (Fluothane, Wellcome Lab., S.A.) in a transparent glass reservoir. The 4th group of animals was exposed to an atmosphere of halothane in the glass reservoir in the same way described for Group III, but without any previous injection of thiopental, until loss of consciousness. The anesthesia was maintained by means of a funnel containing an halothane embedded cotton which allowed an increase or decrease in halothane concentration in the respiratory surroundings of the animals, depending on the anesthetic necessity. Ten animals were maintained as a control group in which there was ro drug injection nor inhalation (Group V).

After $60 \mathrm{~min}$ of anesthesia the animals were sacrificed by cervical compression and, immediately after, perfused according to the method described elsewhere ${ }^{13}$. The worms were counted separately in two portal regions: the first one the liver and distal portion of portal vein and its bifurcation, the second corresponding to the mesenteric veins. The control group (Group V) was submitted to the same procedures.

\section{Second experiment}

A second experiment was performed in female albino mice after 46 days of a transcutaneous infection with 120 cercariae, LE strain, Relo Horizonte. Eleven of those animals (Group VI) were injected with sodium antimonyl gIuccnate (Triostib R, Burroughs Wellcome \& Co., London), $4 \mathrm{mg} / \mathrm{kg}$ i.v., and five of them were maintained as a control group (Group VII).

Statistical analysis in the first experiment was done by analysis of variance and Scheffétest for comparison between means and in the second by Studentes $t$-test, with $P<0.05$ in. dicating significance.

\section{RESULTS}

The first experiment (Table I) clearly showed a shift of worms towards the liver in

T A B L E I

Effect of anesthetics on the shift of adult Schistosoma mansoni worms to the upper region of portal vein and liver, in mice. Worm recovery (mean $\pm \mathrm{SEM}$ ) $=32.75 \pm 5.4$

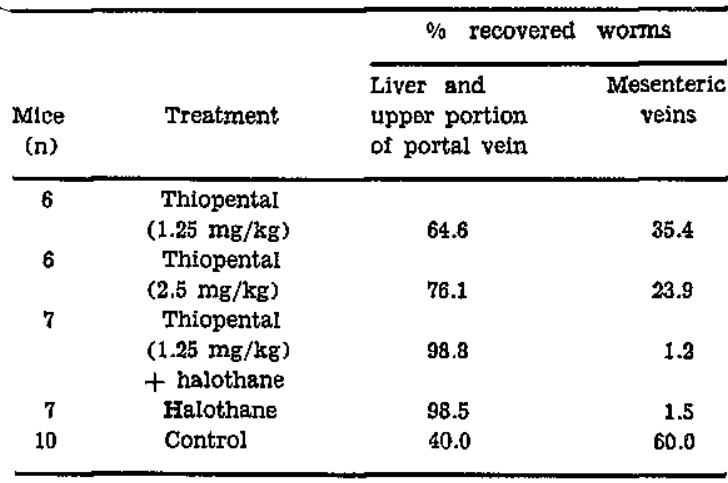

the thiopental-treated group (2.5 $\mathrm{mg} / \mathrm{kg})$ and in animals which had received halothane associated or not to thiopental. In the control group only $40 \%$ of worms were found in the upper portal vein and liver $(P<0.01)$. The group treated with a smaller dose of thiopental $(1.25 \mathrm{mg} / \mathrm{kg})$ showed a shift of $64.6 \%$ of worms to the liver, but this was not statistical ly significant when compared to the control group.

Some mice died due to anesthetic effect. In the halothane plus thiopental $(1.25 \mathrm{mg} / \mathrm{kg})$ treated group four out of eleven died. The sa. me incidence of deaths was observed in group treated with halothane. The animals dead during the experiment were not used for worm re covery.

Table II shows that in the second experiment the pentavalent antimonial (Triostib $R$ ) shifted $52 \%$ of worms towards the liver and upper portion of portal vein. The control experiment showed a shift of $29.3 \%$ of worms to the same regions. The difference between the se two groups was shown to be statistically significant $(P<0.05)$, indicating that the antimonial was responsible for shift of worms but in smaller proportion than halothane or sodium thiopental. 
CUNHA-MELO, J. R. da \& COELHO, P. M. Z. - Schistosoma mansonl: effeots of anesthetics and antimonial drugs worm shift in the mouse. Rev. Inst. Med. trop. São Paulo, $28: 267-270,1986$.

T A B L E II

Effect of sodium antimonyl gluconate (Triostib) on the shift of adult Schistosoma mansoni worms to the upper region of portal vein and liver, in mice. Worm recovery (mean \pm $S E M)=76.1 \pm 9.0$

\begin{tabular}{cccc}
\hline & & \multicolumn{2}{c}{$\%$ recovered } \\
\cline { 3 - 4 } $\begin{array}{c}\text { Mice } \\
\text { (n) }\end{array}$ & Treatment & $\begin{array}{l}\text { Liver and } \\
\text { upper portion } \\
\text { of portal vein }\end{array}$ & $\begin{array}{c}\text { Mesentertc } \\
\text { veins }\end{array}$ \\
\hline 11 & $\begin{array}{c}\text { Sodium antimonyl } \\
\text { gluconate } \\
(4 \mathrm{mg} / \mathrm{kg}) \\
\text { Control }\end{array}$ & 52.0 & 48.0 \\
5 & & 29.3 & 70.7 \\
\hline
\end{tabular}

\section{DISCUSSION}

The practice of extracorporeal schistosome filtration can only be justified when there is a clear clinical indication to operate upon a patient with the aim to treat the portal hyper. tension caused by those worms. The technique of extracorporeal filtration was experimentally developed in baboons by GOLDSMITH \& KEAN, in $1966^{8}$. These authors have poste riorly tested with success the technique in Brazilian human volunteers ${ }^{9}$. Since then the tech. nique has been used many times with good results. However, the utilization of antimonial is not devoid of adverse effects amongst which it can be cited: cough, joint pain, bradycardia, headache, fainting, dyspnea, facial edema, abdominal pain, vascular collapse and cutaneous rashes. Hemolytic anemia may occasionally occur during the course of chronic treatment. On the other hand, the use of antimonials is con. traindicated in patients with hepatic, cardiao or renal failures as well as in massive schisto. some infestation ${ }^{10}$. As the parasitic charge is not usually determined it is very difficult to know which patients are massively infected. Furthermore, patients presenting schistosomotic portal hypertension have, as a rule, different degrees of liver damage and occasionally renal lesions induced by the disease itself.

Some authors discuss the real benefit of the technique to the patient. WARREN $17 \mathrm{com}$ mented that the effects of adult worms dead by schistosomicidal drugs, in the general findings of pathology, would not be a significant feature. This author quoted the results from an experiment done by CHEEVER et al. 6 , in which mice massively infected by worms and submitted to chemotherapy did not present rough hepatic lesions around the dead worms. $\mathrm{He}$ made a relationship between the number of dead worms per $\mathrm{kg} /$ body weight in humans and concluded that the mice infection corresponded to a charge of 100.000 worms in a human adult patient. His work put in question the reasons for applicability of the extracorporeal filtration technique. Nevertheless, an important aspect may be considered, as besides the gross hepatic lesions caused by dead worms, one must remember immunecomplexes formation resulting from simultaneous desin. tegration of innumerable worms. These im. munecomplexes might deposit in distant tissues, inducing lesions in important organs, such as lungs and basal membrane of the kid. neys $1,2,11,12,14,15$. In this way, the mechanical recovery of schistosomes from the portal blood by means of extracorporeal filtration would be advantageous by preventing the formation of those immunecomplexes secondary to dead worms.

Concerning the results of the present paper, the mortality observed after halothane associated or not to thiopental might be explained either by: an overdosage, due to the rudimentary process used for drug administration, in which the concentrations the animals inhaled could not be determined, or by a decrease in the hepatic metabolism produced by schistosomiasis. The infected animal has a small capa. city of drug metabolization since several enzymes of the hepatic microsomal system are depressed $3,4,5,7$. So, it is postulated that animals with schistosomiasis would be more susceptible to the action of halothane.

Our results clearly showed that the effects of thiopental or halothane, drugs routinely employed as anesthetics in general surgical practice, might be sufficient to shift the most of the adult worms facilitating, in this way, the extracorporeal filtration process and eliminating the need of antimonial administration to perform that technique.

The present data reinforce the advantages that extracorporeal worm filtration could bring to the human host, namely: a) avoidance of formation of a great number of circulating im. munecomplexes in tissues from worms dead by chemotherapy; b) with mechanical parasites erradication it would be unnecessary the use 
CUNHA-MELO, J. R. da \& COELHO, P. M. Z. - Schistosoma mansoni: effects of anesthetics and antimonial drugs wormo shift in the mouse. Rev. Inst. Med. trop. São Paulo, 28:267-270, 1986.

of drugs that, in spite of the advances in therapeutics, are still biological poisons, which even having a high specificity against the pa. rasite could induce damage against host tis. sues.

Finally, it must be reinforced that the pro. posed therapeutic process of surgical removal of parasites only could be justifiable in the presence of a clear indication to submit the patient to an abdōminal surgery to treat his portal hypertension or its complications such as bleeding esophageal varices of hypersplenism.

\section{RESUMO}

Schistosoma mansoni: efeitos de anestésicos e antimonial (Triostib $R$ ) sobre $o$ deslocamento de vermes no camundongo.

Camundongos experimentalmente infectados com Schistosoma mansoni foram injetados com tiopental sódico ou antimonial (Triostib R), ou submetidos à inalação de halotano, com ou sem uma injeção prévia de tiopental. Os resultados mostraram que o halotano e o tiopental induzem, respectivamente, o deslocamento de 99 e $76 \%$ dos vermes para o fígado. Gluconato do sódio e antimônio (Triostib $R$ ) deslocou $52 \%$ de vermes. Estes resultados parecem indicar que o uso de antimonial seria desnecessário quando se faz a remoção cirúrgica de esquistos. somos pela técnica de filtraçăo extracorpórea em pacientes com hipertensão portal.

\section{ACKNOWLEDGEMENTS}

The authors are indebted to Mr. Alberto Ge raldo dos Santos, Mrs. Alice Neni Faria Batista, and Miss Zenir de Souza for their technical assistance. They are also grateful to Mrs. Vera de Paula Ribeiro for her suggestions concern. ing the English text.

\section{REFERENCES}

1. BRITO, T.; BONI, D.; LOPES, J. D. \& SILVA, I. C. - Kidney biopsy in human Schistosomiasis. An ultrastructural study. (Preliminary rejort). Rev.' Inst. Med. trop. S. Paulo, 11: 62-64, 1969.

2. BRITO, T.; GUNJI, J.; CAMARGo, M. E.; CERAVALO, A. \&2 SILVA, L. C. - Glomerular lesions in expert. mental infections of Schistosoma mansoni in Cebus apella monkey. Bull. Wld. Fnth. Org., 45: 419-422, 1971.

3. CHA, Y. N. - Inducibllity of the hepatic drug metabollzing capacity of mice infected with Schistosoma mansont. Amer. J. trop. Med. Hyg., 27: 1181-1187, 1978.
4. CHA, Y. N. \& BUPDING, E. - Recovery of the hepatic drug metabolizing capacity in mice infected with Schistosoma mansoni following curative chemotherapy with the schistosomicld 4-1sothiocyano-4'-nitro-diphenylamipe (CGP 4540). Amer. J. trop. Med, Hyg, 27: 1188-1191, 1978.

5. CHA, Y. N.; BYRAM, J. B.; HEINE, H. S. \& BUEDING, E. - Effect of Schistosoma mansoni infections on hepatic drug metabolizing cepacity of athymic nude mice. Amer. J. trop. Med. Hyg., 29: 234-238, 1980.

6. CHEEVER, A. W.; DE WTTT, W. B. \& WARREN, K. S. - Repeated infection and treatment of mice with Schistosoma mansoni. Functional, anatomic, and immunologic observations. Amer. J. trop. Med. Hyg., 14: $239-253,1965$.

7. COELHO, P. M. Z.; FREIRE, A. C. T.; ARAƯJO, F. G.; PELLLEGRINO, J. \& PEREIRA, I. H. - Effect of Schistosoma mansoni infection on pentobarbital-induced sleeping-time in mice. Amer. J. trop. Med. Hyz., 26: $186-187,1977$.

8. GOLDSMITH, E. I. \& KEAN, B. H. - Schistosomts. sis: experimental surgical removal of adult worms. Gastroenterology, 50: 805-807, 1966.

9. GOLDSMITH, E. I.; LUZ, F. F. C.; PRATA, A. \& KEAAN, B. H. - Surglcal recovery of schistosomes from the portal blood. Treatment of the parasitization in man. J. Amer. med. Ass., 199: 235.240, 1967.

10. GOODMAN, L. S. \& GILMAN, A. - The pharmacolo gical basis of therapeutics. 4th ed. London, MacMillan, 1970 .

11. HILLYER, G. V. \& IFWERT, R. M. Studies on renal pathology in hamsters infected with Schistosoma mansoni and Schistosoma japonicum. Amer. J. trop. Med. Hyg., 23: 404-411, 1974.

12. NATALr, P. J. \& CIOLI, D. - Immune complex no phritis in mice infected with Schistosoma mansonl. Fed. Proc., 33: 757, 1974.

13. PELLEGRINO, J. \& SIQUEIRA, A. F. - Ténica de perfusäo para colheita do Schistosoma mansoni em cobaias experimentalmente infestadas. Rev. bras. Ma lar., 8: 589.597, 1956.

14. QUEIROZ, F. P; BRITO, E; MARTINELLX, R. \& ROCHA, H. - Nephrotic syndrome in patients with Schistosoma mansoni infection. Amer. J.-trop. Med. Hyg., 22: 622-628, 1973.

15. Silva, L. C.; BRITO, T.; Camargo, M. E.; DE BONI, D. R.; LOPES, J. D. \& GUNJI, J. - Kidney biopsy in the hepatosplenic form of infection with Schistosoms mansoni in man. Bull. Wld. Hith. Org., 42: 907-910, 1970.

16. VALADARES, T. E.; COELHO, P. M. Z. \& SAMPaYo, I. B. M. - Schistosoma mansoni: aspectos da oviposição (distribulção de ovos nos intestinos e fígado de camundongo e oliminaçäo destes pelas fezes) das cepas LE e CA. Rev. bras. Malar., 32; 53.59, 1981.

17. WARREN, K. S. - The immunopathogenesis of schis tosomiasis: a multidisciplinary approach. Trans, roy Soc. trop. Med. Hyg., 66: 417-434, 1972.

Recebido para publicação em 26/9/1985 